\title{
A Culture of Conflict: An Examination of Thought Processes and Subsequent Behaviors of Citizens in Post-War Belfast
}

\author{
Nicole Finnell Smith
}

\begin{abstract}
This article is an exploration into the thoughts and behaviors of the citizens of Post-War Belfast. More than twenty years have passed since the declared end of the Troubles, a three decade-long civil war taking place in Northern Ireland. While many places in Northern Ireland felt the blows of this war, it seems that none felt them quite as badly as Belfast. In this article, I examine the behaviors and actions via the thoughts and perspectives of citizens of Belfast, a city which is still torn in half, divided by forces such as religion, politics, and law among others. These forces are intimately entangled with one another, so much so that the root of the conflict proves difficult to find. After examining the history of Belfast and its peoples, I create two provisional categories, "those too close to the conflict" and "those too far removed from the conflict." By doing so I am able to explore what is deemed the normative thought processes of varying people groups, which helps outsiders to glean some understanding of their behavior. In the end, my goal is to give voice to varying sides of the conflict, and while not giving any solution to the conflict, I aim to offer some knowledge and insight as to why it is taking place.
\end{abstract}

Despite the numerous attempts at peace and years of planning for resolution, the people of Belfast, Northern Ireland still live in a culture of conflict, a culture built on conflict and sustained by it. Though some experience Northern Ireland as peaceful, I argue that this "peace" is surface level. Indeed, all citizens of PostWar Belfast belong to one conflict or another, which places them in provisional categories I have deemed as "too close to the conflict" and "too far removed from the conflict." Whether a denizen of Belfast could be characterized as being "too close" or "too far" from the conflict depends upon which framework has been given to her. Every individual in society lives according to a given framework, a way of thinking and living which is set before her. In Belfast, there are multiple competing frameworks, each laid by different groups within society. If a person is to make sense of the conflict embedded in Belfast's culture, then she needs to start with the thoughts and perspectives of the peoples and their diverse backgrounds. Behavior, no matter how bizarre or uncouth it may seem, makes more sense when the "why" behind it comes to light. In order to uncover the conflict beneath Belfast's seemingly peaceful surface, I provide a detailed explication of how cultural situations/frameworks influence individuals' beliefs and (therefore) actions, then I apply this theoretical lens to the history of Northern Ireland and Belfast, specifically approaching my first-hand experiences of Belfast and its people through this theory. I conclude this article with some ruminations on conflict resolution and its possibility in Belfast.

\section{Humankind's Thought Capabilities}

In 1910, Franz Boas published an article titled, "Psychological Problems in Anthropology," in which he addresses the mental capabilities of humankind. He writes, "A fundamental problem of anthropology relates to the mental characteristics of [differing] social groups" (Boas 1910, 372). He informs his audience that men and women of different social strata behave differently, and they cannot be expected to act in the same manner as someone from an entirely different place, time, or social group. Biology, at a ground level, plays some role in thinking, in developing human mental capabilities, but it is the environment, one's 
reaction to his or her own society, that ultimately determines a person's specific thoughts, and subsequently, the individual's behavior (Boas 1910, 374).

Therefore, the issue at hand regarding the mentalities (beliefs, behaviors, and lifestyles) of those who inhabit Belfast, Northern Ireland is, first and foremost, an environmental one. The people of Belfast exist in a specific environment, a particular, historical society arising from various cultures. They exist within an entirely unique social structure. According to cultural relativism, a term generally attributed to Franz Boas, it is neither permissible nor ethical to compare the behaviors of one culture to another because each culture, or subsect of culture for that matter, acts and thinks according to its own social structure and history. It is for this reason that an individual who has not known war personally, or experienced terrorism close to home, cannot judge the actions of any who grew up during the Troubles (a 30-year civil war fought among inhabitants of Northern Ireland between 1968 and 1998) or continue to live in the conflict of Post-War Belfast.

On the opening page of Ruth Benedict's book, Patterns of Culture, she shares a proverb taken from an Indian culture she once studied. The proverb says, "In the beginning God gave to every people a cup of clay, and from this cup they drank their life" (Benedict 1934, v). It is that cup, which is given and not chosen, that decides each person's life. There are two levels at which individuals gain their understanding of the life in which they find themselves. In their book, The Social Construction of Reality, Peter Berger and Thomas Luckmann refer to these as, primary socialization and secondary socialization. The former is a general understanding gained in childhood and common to all in society, and the latter is specific to one's role or place within that society. Taken together they create established perspectives, habits and routines (Berger and Luckmann 2011, 155). That which is perceived as routine in a culture becomes that which is perceived as constructive and "good" (Kapur and Campbell 2004, xi). I will discuss this in detail in the following section.

Applying the proverb cited by Benedict to Berger and Luckmann's levels of socialization, the former, primary socialization, is the cup given to the individual, i.e. the framework which is laid down for him or her. In order to live successfully within the culture, he or she must drink from the cup, there is no choice. The latter, secondary socialization, is when the individual drinks from the cup, and must now live on his or her own according to the content of the cup, i.e. making his or her own choices according to the framework that has been given. Every human is exposed and subject to his or her social and cultural framework. She is subject to her culture, she is subject to primary and secondary socialization, she is subject to the cup.

Children born in Post-War Belfast are handed a cup which is filled with hatred for those who are not like themselves, a cup that is void of empathy for the other but does not lack love for one's own religion and politics. Adults in Post-War Belfast have drunk from the pages of history books which tell of war, biasedness, and corruption. The cup, filled with antipathy, ran over during the Troubles. These are those thoughts and beliefs which have been passed down through history, and so these are the things which have become a reality for so many in Belfast.

\section{Understanding Behavior via the Cognitive}

A person's thoughts say a lot about her. They say what she believes, what she understands as truth, and how she sees the world around her. What a person thinks typically guides her behavior, and how she thinks will determine if she feels burdened and weighed down by stresses of her own reality, or if she feels light-hearted and free from that burden. Her thought process is the starting point for the being that she is. There is reason for the emphasis put on an individual's thinking processes when she is developing, there is reason as to why the author of Corinthians encourages his audience to take every thought captive and make it obedient to Christ (2 Cor. 10:5). It is not impossible that if a person's mind can be changed, then her surroundings can be changed as well. This notion, that changing a person on a mental level yields change on a behavioral level, is what has encouraged many scholars of Belfast to believe in the possibility of change. However, Belfast is currently (as it always has been) an environment saturated in conflict. This conflict continues to produce thoughts of tension and separation. There is a constant division in the city because there is a consistent dividedness in the thought processes of its inhabitants. They have learned to think about certain issues in such starkly different ways that commonality in their thinking (and thereby their behaviors) seems nearly impossible to find.

The following pages explore the ways in which differing subsects of communities in Post-War Belfast think and perceive the world around them. The stories are not intended to offer a solution to the conflict nor are they there to extend advice on any one way that a single individual can change the thinking of an entire city. Rather they are intended to provide insight into and understanding of the conflict that still rears its ugly head. There are hints of the possibility of change, and descriptions of efforts being made towards peace and the elimination of conflict here, but the primary purpose of this article is to give voice to the many sides of the conflict in Belfast. The conflict is not always two 
loud and boisterous voices yelling obscenities at one another; sometimes it is a cacophony of voices, some whispering, some whimpering, and some protesting in silence. However the conflict presents itself, it is the perspective of the voice behind it that I seek to make known.

The perspectives offered in the following pages have been sorted into two provisional categories: "those who are too close to the conflict" and "those who are too far removed." While I found that there are no clear lines as to where conflict resides and where exactly a particular conflict originated, it can be said that every conflict involves people with one or the other of these two mindsets, and it is the mindset which determines how each individual treats the conflict at hand. Those in the former group possess a mentality of conflict from birth, via projection and tradition. Those in the latter group are brought into conflict by the mere fact that they do not comprehend the conflictive nature of the thoughts and behaviors of those who belong to the former. This puts them in tension with each other because they cannot understand one another. Conflict in Belfast is messy, but it is human. No person can look at Belfast and ask it to be any other way. The city can only be understood via its people, and its people can only be understood via their behavior, which is the result of their thinking.

\section{"Too close" and "Too far removed" Explained}

As articulated in greater detail in my full-length thesis, history reveals that conflict has been present in Belfast since the starting days of Ireland itself, before "Belfast" was even a name (Smith 2018). The Troubles at the end of the last century were the result of a fiery conflict being hit with copious amounts of gas and kindling. Two decades later, the heat of the embers is still felt by every person who calls Belfast home. With over eight centuries of conflict present in its history, a person may wonder what this has done to the normative thought processes and understanding of a person in Belfast. During my time among the people there, I sought to answer questions which would glean some deeper anthropological understanding of the city: what is the reason behind the inability to find agreement and bring about peace? Furthermore, given the city's history and current predicament, is there potential for a new culture of cognition in Post-War Belfast? In the following sections of this article I argue that each of Belfast's citizens, regardless of which feuds they fight, as there are many, belong to one of two groups: "those who are too close to the conflict" and "those who are too far removed."

Those who are "too close to the conflict" and "those who are too far removed" could easily be described, respectively, as the bitter and the idealistic, although neither can be blamed for being as such. This idea is supported by Bill Meulemans, a scholar of conflict in Belfast, and Professor of Political Science at Queen's University of Belfast. Meulemans notes that those who are of working-class origin, that is, those who live paycheck to paycheck without hope of moving up the economic and social ladder or onto something better, identify wholly and completely with their own people. Meulemans says that it is because of this identification that it is "beyond their [the working-class] comprehension to feel what the other side feels" (Meulemans $2013,63)$. Those who go out into the city each day and see it for what it is, a place where bombs are still found, murders still occur, vandalism still decorates the streets, and imaginary lines still maintain division, are the ones who fall into the group "too close to the conflict." These are those who cannot help but feel heartache for their own people and hatred for the other. Those who hold the seats of power in the city, the ones who see Belfast once again thriving with tourists, the ones who are aware of the slight increase in Belfast's dilapidated economy, are the ones who are hopeful for what is to come. They reap the benefit of a war commodified, because they see the numbers grow daily, and they feel it in their pockets. They are "those who are too far removed".

\section{Cognitive Processes}

In the same vein as my own efforts to approach the culture of conflict in Belfast's neighborhoods from a cognitive perspective, understanding the root of the chaos to be a matter of the mind, so Raman Kapur and Jim Campbell have also concluded that the seemingly abnormal, that is viewed as normal in Belfast, stems from a troubled thought process (Kapur and Campbell 2004, 14). Raman Kapur is a consultant clinical psychologist and psychoanalytic psychotherapist, and he lectures at Queen's University Belfast on mental health, concerning himself primarily with matters of terrorism and trauma. Such a specialized focus makes Kapur a credible source where the cognitive and mental processes of the people of Northern Ireland are concerned. Co-writer Jim Campbell has experience as a mental health social worker in Northern Ireland and has worked for many years exploring different analytic techniques that have helped others understand the Troubles more clearly. In a full-length study, focused solely on members of Belfast's communities, Kapur and Campbell ask a question I explored during my time there and the subsequent months after: how is it that a human being can think violent and harmful actions, such as taking another's life, for whatever reason, is a good idea? I have concluded from my experience in Belfast, as Kapur, Campbell, and most anthropologists do, that a human being's way of thinking begins first 
with socialization, an introduction to one's social and cultural framework by those who are already familiar with the cultural mindset and therefore deemed adequate for laying the foundation of a conceptual framework.

Kapur and Campbell use Kleinian psychoanalysis, a particular method that focuses on the development of human relationships by sorting that which is good, or constructive/creative, from that which is bad, or destructive/deadly, to determine where these thought processes originate (Kapur and Campbell 2004, 14). Kapur and Campbell use this method to explain how "sane and rational" parts of our mind can be taken over by parts that are "less human" if they are put there by behaviors deemed normal by one's family and peers (Kapur and Campbell 2004, 16). The key idea here is "what is deemed normal." To maintain structure, stability, and repetition in life, according to Kleinian psychoanalysis, is constructive because it builds routine. Therefore, if the routine contains that which is "bad" or violent and harmful, with time it can flip a person's thinking process into believing that the "bad" which is experienced as routine is actually normal and therefore "good". Their argument, to put it in concise terms, is that excessive exposure to violent and destructive acts causes the abnormal to become normal (Kapur and Campbell 2004, xi).

In their study, Kapur and Campbell seek to identify the ideal environment and circumstances under which people's thoughts can be altered to relate to one another in more humane ways. Kapur and Campbell take their experiences in Northern Ireland and try to find a solution for the trouble they witness there by first understanding the way in which people have come to think of one another, and then by identifying the relevant elements in their environment. By dialoguing with groups of Protestants and Catholics, across age, race, and socio-economic demography, they inquire whether each person's perception was taught by another individual or is the result of a personal experience. Their study has concluded that the majority of those living in Belfast now who were not directly affected by the Troubles have gained their understanding from those around them, learning "illwill and bitterness from the breast" (Kapur and Campbell 2004, 31).

Keeping this in mind, that conflict (antipathy, separation, difference, etc.) is learned/taught, in the following sections I begin to uncover the contemporary situation in Post-War Belfast by first examining its history, the place in which these ideas were first developed. As the history of the city unfolds, Belfast's propensity for conflict comes to light. Through this lens, I tell the stories of very different people, all of whom live vastly different lives according to their own histories and their own truths. The way in which they share their stories, their histories, their experiences, their truths, is all a direct result of the way in which each of them thinks. There are violent thoughts, perceived to be no less than normal, which belong to those who live in the conflict every day. There are hopeful thoughts from those who have travelled far to make Belfast a better and safer place. There are thoughts which cause the mind's eye to see Post-War Belfast as one big memorial and burial ground, and there are thoughts which lead its owners to envision Post-War Belfast as a prosperous and thriving city. Whatever the perspective, it begins in the mind. To create change, we must start here.

\section{Conflict Embedded in History and Culture}

Ask the majority of Northern Ireland scholars and residents of Belfast when the Conflict, also known as the Troubles, began and most likely you will hear either the 1916 Easter Rising or the summer of 1969 (Feeney 2004,7). But truly, conflict has been embedded in Northern Ireland's history since the first record of British involvement in 1170 . In the 848 years since then, there have been just three decades of what historians might call "peace” (Maguire 2009, 72-81). Even still, these "peaceful decades" were between the late 1700 s and early 1800 s, a time in which, while Belfast was booming in industry and trade, penal laws were in place that kept Irish Catholics from obtaining an education, having the ability to vote, speaking their own native language (Gaelic), and living with basic human rights. With such laws in place, one could hardly call this time, "peaceful." Indeed, one can trace a history of conflict in Belfast, in its religion, its politics, its law, and in the control of information, since its very beginning.

In every century we can find a battle, a revolt, or a scheme which takes the reigns of power over the land from one religion to the other, shifting from one leader to the next. The whole history is full to the brim with massacre, mutiny, and malicious behavior from its inhabitants and usurpers alike. The short of it begins when King Henry II, along with several English Barons, began to seize Irish lands in 1171 after a two-year battle known as the Norman invasion of Ireland (New World Encyclopedia 2008). For nearly 200 years afterwards the land was fought over by the Irish and the English. By the end of the 1300s, all of the land in Ireland had fallen under English control and crown rule. However, as nearly two centuries passed, the English Barons and their subsequent companies began to view themselves more as Irish than English. Such a mentality (again a key player) meant that loyalty to England started to weaken (Maguire 2009, 13). In 1534, with allegiance to the crown at a severe low, King Henry VIII decided to take back control by invading the Irish island, as his 
predecessor had, and instituting laws that gave England more governing power, including declaring himself to be "King of Ireland" in 1541. To this day, via politics, paramilitaries, and peaceful protests, Irish civilians are still trying to fight for national freedom. King Henry's war still rages. The conflict that began in the 16th century saw its climax four centuries later, and it has not stopped yet.

The timeline of Ireland's history can be viewed from either Irish or British perspectives, depending on the ruling party at any given time. At no single time in history can Northern Ireland be labeled "Irish" or "British" because her inhabitants have always been, and are, a blend of both identities. As for Belfast specifically, the pot did not melt as well as one may have hoped. The city possesses both identities, from the domination of the British and the ruling by the Loyalists to the revolt of the Irish and the rise of the Nationalists. History demonstrates that Belfast has always been home to the Protestants and the Catholics, to the Unionists and the Nationalists (Maguire 2009, 16). But to ask any of its inhabitants is to hear of a land that has always belonged to one group entirely, while the other has fought to take what is not rightly theirs.

King Henry VIII claimed the land as having belonged to his ancestors because the British Royal Army had saved it from foreign invaders in the late 1100 s. To this day, Unionists in Post-War Belfast give their loyalty to the crown for its role in this war. As for the Nationalists, they look to Ireland's history to show how forgotten Ireland has been, and they paradoxically take pride in a history that shows Ireland as capable of thriving without assistance from the crown. These two mentalities are at odds, and where there is friction, over time there is conflict.

The in-depth details of the multitude of conflicts presently being fought in Northern Ireland can be read in my full-length thesis (Smith 2018). For the purpose of this article I will explore the broader areas of conflict that are evident in Belfast now. These areas are religion, politics, law, and information.

\section{Religion: Protestant versus Catholic}

Religion has been the reason for many wars in history. Northern Ireland is not unique in that. Perhaps what is unique is that religion has been the source of a 400-year war there. Northern Ireland is not torn over land, nor money, nor resources; it is torn over who owns the land, who makes the money, and who possesses the resources. Ownership, in the eyes of many of Belfast's citizens, must either be by the Protestants or the Catholics, it cannot belong to both. It cannot be shared.

There is a folktale in Northern Ireland that tells of the founding of Belfast and the claiming of Ireland. It is said that there were two chieftains, one a Protestant and the other a Catholic, sailing at sea, side by side, when the company of both ships noticed a beautiful piece of land in the distance. Of course, both chieftains wanted the land for their own. Knowing that there could be only one ruler, the two men struck a deal. Whoever touched the land first would be the one who owns it. Now, there are many versions of this story in Northern Ireland, and there are even speculations as to who these two chieftains may have been, but the thing which all agree upon is this: when the Protestant chieftain saw that he was losing the race to shore, he cut off his left hand and threw it onto the land. As per their agreement, the hand-less ruler became king of Ireland. Where the story stops or continues is circumstantial and depends entirely upon who is telling it. A Protestant may end the story there and point to the red hand which decorates the flags of Protestant areas in Belfast, saying, "The red hand of Ulster. It is a reminder that we have always won, and we always will.” A Catholic, on the other hand, will undoubtedly continue the story, perhaps by remarking, "What they don't tell you is that the Protestant bled to death before he got to land. They may own it, but we rule it. Always have, always will.”

Like the end of the Catholic's story, there is a real sense in Belfast that the power does not lie with those in elected authority but with the people. After the Good Friday Agreement was proposed and passed in 1998, civilians of Belfast on both sides began to feel disappointed with the results of the agreement. Where peace was promised, conflict grew. The Good Friday Agreement, also known as the Peace Agreement, was an arrangement between Catholic and Protestant leaders in Northern Ireland and in the Republic of Ireland as well. The agreement worked to establish an independent assembly in Northern Ireland that would not be dependent on the Republic of Ireland for political decisions. The agreement was to give shared power to both parties, the Protestant Loyalists and the Catholic Nationalists, in Northern Ireland. But as we have already discussed, power cannot be shared in this context. The agreement was supposed to establish a relationship between the governing powers of each religious/political party in the North and maintain a civil relationship with the governing powers of the South, and in doing so establish the same kind of peaceful relationship between the respective citizens of each group. However, the establishment of better bonds between the governing powers did not do the same for the working class. Then, when there was a failure in vertical unity, that is the governing authorities chose not to disburse resources to those who lived below them socially and economically, the citizens refused to establish unity horizontally, that is with the religious "other" residing in their own working class. 
This difference between the mindset of the governing class and that of the working class illustrates my point that Belfast remains utterly divided because of the gap that exists between those who are "too close to the conflict" and those who are "too far removed." When an individual is too close to the issues at hand, he or she cannot possibly feel empathy for those who inflict pain on people he or she cares about. When an individual is too far removed from the conflict, he or she possesses a capability to hope for something better, to work for peace, and to believe it to be a possibility. Something as simple as "being capable of hope" is a characteristic which belongs solely to those who are "too far removed from the conflict" because those who are removed, those who are in power, are those who reap the benefits of the city's economy, they are those who will prosper from peace.

The struggle between Protestants and Catholics continues because the majority of Belfast's people reside among "those who are too close to the conflict." Without an official role in government or Parliament, the only power these people believe they possess is in their religious identity. It is identity which made the Good Friday Agreement crumble just four months after it was signed (Feeney 2004, 122). The agreement banned paramilitary groups on both sides, which is what made it appealing to the majority of the general public, but it came with unresolved problems. The Irish Republican Army (IRA) was not yet ready to give up what power it had gained during the 30 years of the Troubles. Catholics had been oppressed by the Penal Laws which penalized the practice of Catholicism for too long, and many feared the agreement would lead back to the same oppressive state. With that thought in mind, the IRA continued as it had before the agreement, and the Protestant paramilitary groups returned fire with fire (Feeney 2004, 129).

Belfast's City council says the Troubles ended with the Peace Agreement. The people of Belfast could argue that the agreement brought a bigger divide. The loyalty of the Protestants to the crown grew significantly as they waited for Britain to send help. The Catholics felt closer than ever to their Irish roots, determined to rid their country of those who were disloyal to it. I learned this part of Ireland's hostile history from Kyle, a man I met when visiting at the Parliament buildings. Kyle works there as a civil servant and is one of the few people I met in Belfast who did not favor either side of the conflict. At nearly 40 years-old and committed to his contract, he knows a thing or two about life and loyalty. He said his role in Parliament forbid him to "lead on like he was on either side." What he was able to share with me confirmed my contention about the role of religious identity in Northern Ireland: it is everything.
"There can be no mistaking a person's identity here," Kyle said. "History has given us enough time to figure a way of knowing what every single person believes." Kyle supported this statement by sharing the story of his parents, both of whom belong to the deaf community. "Before the stark segregation here, the deaf were a community by themselves, it didn't matter if you were Protestant or Catholic. If you were deaf . . .," here, he signed something to me, “ . . . you are a friend. When it got to the point that neither side wanted anything to do with the other in any way, they even made Irish Catholics use their own one-handed sign language while Irish Protestants had to learn British Sign Language, which requires two hands." He paused for a moment. This was the first time all day that he had shown any emotion outside of the professionalism he had displayed. "It tore the deaf community apart, as everyone is torn apart here."

Such division has left some natives of Belfast, deaf and hearing alike, with a feeling of confusion and disappointment. Two natives who can attest to this disappointment are Sean and Minnie. The former is a native of the Republic of Ireland and the latter of Northern Ireland. I met Sean and Minnie in Whites, Belfast's oldest pub. Both in their seventies and dressed well to-do, they were easy to make conversation with regarding the topic of conflict in Belfast during the Troubles. Sean and Minnie had married in 1972, a peak time of the Troubles, when he was a Catholic and she a Protestant. It was the location of their meeting, says Sean, that made their marriage possible. They met at work in London. Minnie left for London during the early years of the conflict and Sean had transferred there for his job. "Had we met here in Ireland, we never would have looked each other's way," Sean said, and gave Minnie a playful nudge. "A girl brought up in a Protestant home would have snubbed her nose at a Catholic from County Wexford." County Wexford is in the southern and most eastern corner of Ireland, and its population is $89 \%$ Catholic (CENSUS 2016). While thought to be relatively removed from the tension in Northern Ireland, it can be said that the Irish Catholics in the South felt the same way about British-identifying Protestants as any would in the North. Minnie converted to Catholicism before marrying Sean, and the transition has "opened [her] eyes to how wrong and backwards people can be.” As a result, she holds a bitterness against those who raised her and taught her as a child.

"I'm Irish, and I know nothing about my country's history. Isn't that sad? Nearly 73 years old, and I'm just learning what the school kids are learning. Pathetic is what it is . . not knowing who you are.” Minnie grew up in a small village just outside of Belfast. She went to a school where the students were taught British history. They did not speak the Irish language (Gaelic), and they 
were not informed about the laws in place which kept Irish Catholics from having the same rights as they did.

"Of course, we knew though, right? Maybe not in so many words, but we knew something was different. We knew we were separated for a reason. We knew not to go near them, and they knew not to come near us. If the two mixed, nothing good came from it. Children may not know everything that's going on, but you can't ignore something like that." Minnie was speaking of her childhood, a time before the Troubles began, but still there was conflict, as there has always been in Ireland. "They let us out at different times too. Protestant schools dismissed fifteen minutes earlier than the Catholic schools." Dismissing the school children at different times was a safety tactic, it restricted intercommunity contact. This tactic continues today, not to prevent communities from all interacting, as some interaction is a hope of the Good Friday agreement, but to prevent injuries and deaths that occur due to fights between the youth (McAlister 2013, 8).

The governing powers of Belfast planned for peace. They promoted it on websites and flyers as though it was already in progress, as though the violence had disappeared with the turn of the century. However, as I was discovering, this was not the case for the everyday citizens of Belfast. Sean had remained quiet for a good deal of our conversation, inserting a grunt or sound of confirmation here and there as his wife spoke, but I wanted to know how he felt about the conflict which was obviously still in existence between the Protestants and Catholics. "Everyone has opinions," Sean said, "It's best not to share them."

\section{Politics: Unionist versus Nationalist}

There is not much of a separation in Belfast between the religious and the political. Its theology is engrained into its politics and vice versa. It is thought by some historians that religion was first introduced into Irish politics in the mid-1500s, during the time when King Henry VIII stormed Irish lands in order to conquer them and gain back loyalty. It was during this invasion that one Lord Offlay of Ireland rallied supporters for an Irish Crusade. That is, with the ensuing victory of the crown over Ireland, he did not want the Protestants to have the power to control the Irish. He began to make his religion an integral part of his politics.

For all of the people with whom I spoke, religion and politics are intimately tied together, making it impossible to speak of one without speaking of the other. Jack is one of those informants who deeply believes this. He has been persecuted because of his religion, denied access to basic human rights such as education and work because of the religious beliefs he has inherited. It is this that led him to participate in the
Irish Republican Army (IRA). The IRA is an extreme paramilitary group associated with strong nationalistic and Catholic viewpoints. Jack first came to support the IRA when he had had enough of the abuse he and his family frequently received from Protestant authorities.

"They didn't want us to learn, afraid we would outsmart them, rise up, and take control. So, what do they do? Same thing they've been doing for years anytime they fear they're losing control: outlaw education for Catholics." Jack had a look in his eye, he was waiting for me to say something, to show that I'd taken his bait and absorbed his story. Jack is a big man, bald, tall, and covered in tattoos. The tattoos tell stories of his life, just as he does for a living. Jack gives "black" tours to visitors, tours meant to give the "real and gruesome" details of life in Belfast. Because there is not much else that his past qualifies him to do other than drive a taxi, Jack makes extra money for his family by providing guided tours and telling his stories, every story told with that same look in his eye. Even when Jack told stories that were miserable and might leave listeners aghast, he had that same look. I tried to read what it was, but I did not have to try very hard. His next words showed me what that look was: pride.

"What do we do in return? We say, 'you don't want to give us schools, you don't want us to speak our language? Fine.' So, we don't go to their schools. We meet in caves and holes dug out in the mountains, we send children to school at night, and we teach our children there. We teach them everything they need to know to be brought up educated in the world, and we teach them the truth. By the time us Catholics are allowed back in school, we aren't far behind the others. Hell, we're beating them." Pride. That is exactly what the look was. Anyone close to the conflict and divided on any issue carries that same look of pride. The gruesomeness of the story being told or the results of failure at the end of a battle did not matter, the tellers were proud of "their side," and there was not a thing in the world that could deflate that pride. I asked, "Jack, what did you mean by you teach them truth?" Jack's story of the underground schools being taught in the dead of night was fascinating all by itself, and it gave life to the texts I had read and the caves I had seen just a week before, but it was his intentional insertion of "truth" that caught my attention. "We make sure they know their Irish history, who they really are, and what they came from. We also make sure they know who is there to help them, and who to stay away from. We teach them the necessary means to survive as an Irishman [and woman] in Belfast, ran by Protestant crooks and dirty police. We make sure they know life is unfair and why it's unfair."

As I listened to Jack's story, I realized how desperately he wanted this truth to be known, not just by Irish children, but by anyone who was willing to 
listen. I remembered the sports playing field Jack had shown me within the first few hours of meeting him. This was before I knew of his involvement in the IRA, and all he was to me then was a man who took my husband and me on a "political tour" of Belfast. He had showed us a relatively new field, complete with four nets, two basketball goals, green grass that had been recently cut, high wire fences, and more than 90 Union Jacks that waved above the field. "The city puts in a nice playing field in the Protestant neighborhoods and the Catholic children play in the streets or in the garbage lots. Tell me they aren't putting money where religion is."

He was speaking of those who sat on the city council, those like Alderman Colleen, who directed where the city's funds would be placed. Alderman Colleen works on behalf of the city's Peace Programmes, projects sponsored by the Belfast City Council to help residents and tourists alike feel more secure in Post-War Belfast. Adjustments and amendments have been made to the Peace Programme since 2005, and Belfast is now on its fourth draft and plan of implementation of that same Peace Programme. The projects, according to the alderman, are funded by the European Union, and there are people put in charge of those funds making sure they know where every pound is spent. Alderman Colleen told me that the money from the program will go towards areas they feel are most in need of reconciliation, such as youth services, the housing market, and other departments that the council believes will promote the idea of peace it is trying to cultivate among the citizens of Belfast. Unfortunately, the main difficulty with this seemingly good plan is that it ignores the fact that Belfast is divided. There are not simply youth services and housing markets, but Unionist youth and Nationalist youth, and Protestant housing and Catholic housing.

Following my conversation with the alderman, I walked through city hall to see the information that is presented to the public. Most of the posted material reflects images of a more united city than is the case in reality. The room which speaks to this disconnect the most is called "The Reflection Room." Inside, there are twenty or so quotes which, in one way or another, all say that Belfast as a whole is hurting, but in the end, it is the hurt which brings people together and helps them forget their differences. One particular quote comes to mind. The Council has written in large writing:

I met one other woman from North Belfast whose husband had been murdered by the IRA, and we talked and we just hugged each other, and it was nice. She had the same hopes, she had the same fears that I had and both our concerns were for our families . . . And to think that you don't know what grief people are carrying around . . . It's given me patience and it just helps, just gives you a bit more understanding. I don't care if you're Protestant, Catholic-I don't care who you are or what you are-your grief is still the same.

Such a gesture warmed my heart when I saw it, but those who are much closer to the conflict are not buying it. One informant, when asked about how she felt when reading this quote said, "Who in their right mind is going to forget that their family was killed by the IRA and just forgive 'em when they're still out killing people?" The quote was applicable to Unionists and Nationalists alike, but in her mind, she had already identified the villain.

\section{Law: Police versus Civilians}

"Do you see those letters there?" Jack pointed to graffiti on the side of a trash can. If he had not taken the time to point it out to me, I would never have thought to notice the white letters scribbled on a muddied silver can. The two elements, white ink and hard mud, were close enough in color that the naked eye scanning the scene would most likely not have seen it. "'K.A.T.' You know what that means?" He asked me, once again with that look of pride in his eyes. I informed him that I did not know what it meant, but I had seen it written on doorframes and shop walls. "'Kill all Taigs.' That's what it means. And you know what a Taig is don't you?" I had done plenty of research prior to my arrival in Northern Ireland; however, I think Jack expected me to know a lot more than I did.

"I think you all call them 'pigs' in America." A cop. Jack had pointed out a marking on the street, a marking which covered many parts of many different streets, which both supported the idea that one should kill all cops and potentially confessed to having done so. "Are those put around town by members of paramilitaries?" I chose to phrase my question as such, because I did not want to allow for the possibility that Jack might think I was too quick to blame the IRA for anything.

"Sure. Maybe." He shrugged, and then he continued, "Doubt it. This graffiti and junk everywhere supporting the IRA, the UFV, the RUC, I can guarantee you that wasn't put there by members of any of those groups. It's put there by the people."

"So, the people are saying kill all cops?" I sounded a bit suspicious. Why would civilians want police officers dead just for the sake of having them dead, especially in a time as troublesome as now? Jack did what Jack did best and broke it down for me, helping me piece the puzzle together. "Where were you when you saw K.A.T written on the buildings?" I noticed that Jack was now starting to talk to me as though he was 
teaching me and not merely informing me of "his side" of the conflict.

"Well..." I thought out loud. My husband and I had made note of these marking when we had first arrived, and by this time, I had not remembered the name of the streets we were on; however, I did remember one street because it intersected Crumlin Road, the area in which I was staying while on my trip. "Falls Road has a lot of graffiti with those same letters."

"Precisely." Jack looked at me as though he had given me the answers to all of my questions, "Falls Road belongs to the Catholics, and the police force belongs to the Protestants. All they're good for is raiding your homes, pulling you over for no reason but to mess with you, and not doing what they should to help you when you actually need it. Taigs aren't anything but something else for us to worry about. The Catholics don't want them here anymore than they want us here."

If the feeling is not made clear enough by the graffiti that marks the walls, it is made clearer by the billboards and posters which have been placed in Catholic Neighborhoods. At the intersections of each street, where the police have installed their cameras and put up their fences, the Catholics have hoisted signs which display three interdictory circles. The prohibition signs cover the acronyms of the Police Service of Northern Ireland, the United Kingdom's Secret Service, and the British Army.

If I thought that prohibiting the police from a neighborhood was odd, even more odd was the fact that the police obeyed these signs. "Jack, if police aren't allowed in Catholic neighborhoods, how are they kept safe?" The question seemed simple enough, but the answer opened up more inquiries.

"The IRA act as the policing force in these areas here," Jack said, as if it were common knowledge. He most certainly had noticed the look of confusion on my face. "You see you have to remember, there are the official IRA members, who are our police. Then there are Provisionals, who are the ones doing the fighting behind the scenes. We also keep the streets safe, so the people around here, they don't mind us." Jack then proceeded to tell me of how the Provisional IRA handled a drug deal that went down just last week. "We saw the guys selling and buying, grabbed 'em, shot one through the wrist and the other through the ankle. They won't be bringing that stuff around here anymore." He said it calmly and nonchalant, as though these were every day average activities. "Look, we want our streets clean from crap like that, so the people keep us around.”

In Post-War Belfast, there are areas where it is the police that need to be protected from the civilians, and there are areas where the civilians need protection from the police. Kyle, the civil servant whom I mentioned earlier, had something to say about this situation.
"Statistics are proof, numbers that can't be fabricated. The amount of crime reported in Belfast has gone down." I wonder if he intentionally chose to word his phrasing that way. "The amount of crime reported." I thought back to every instance of revenge and vigilante justice that I had heard of during my time in the small city. The crime reported has gone down because the citizens of Belfast have taken matters into their own hands. All parties feel as though the law is biased and corrupt, because they know of their own biases and capability to be corrupt. As the conflict makes the divide between Protestant Loyalists and Catholic Nationalists grow bigger and be felt more deeply, so it also widens the divide between the governing powers and the citizens. It is the latter who feel the pain of the Troubles more harshly, it is the latter who live close to the conflict while the former are able to remove themselves at the end of the work day. Therefore, it is the latter who have decided the law must be taken into their own hands.

\section{Information: Media versus Murals}

Mary was the first to show me the murals. Rather, she was the first person to provide context and background information to a few of the more wellknown paintings. Any person who steps foot on soil in Belfast will undoubtedly notice the murals on his or her own. A person doesn't need any help in discovering them. There are thousands of painted murals filling the sides of every building, alleyway, and wall in Belfast's small forty-four square miles. They tell of Belfast's historical timeline, starting with pictures that portray its founding, and ending with the more recent murals that honor lives lost just days ago. The murals span centuries, centuries of feelings, centuries of battles, and centuries of life in Belfast. The political paintings that commemorate lives lost or victories during the Troubles remain year after year, but others are painted over and new stories are told through them.

Mary was young, in her mid-to-late twenties, and while she did currently live in a Belfast that was full of conflict, she was born after the worst of the Troubles was over. What she could say about the murals was said as if it was read from a script written for her by a father who was filled with hatred for the Catholics and a mother who did not trust people who were different. Like any method actress, she believed every word of what she said. Her parents' truth is her truth, their hurt is her hurt, their triumph is her triumph. For people like Mary, there is no need to experience the conflict first-hand when the conflict has damaged one's family so deeply, the residual pain is enough. It is the pain that she sees in her family that puts Mary too close to the conflict. It is the pain that she sees, hears, and relives through her parents that inhibits empathy for Catholics. 
As with many of the youth in Belfast, her reality has been created by what has come before her.

Mary's story reminds me a lot of Jack's. For obvious reasons, such as biology, age, religion, and personality traits, Mary and Jack are starkly different; however, they are both so filled with resentment that they are more alike than either might be willing to admit. I recorded my time with Mary so that I would remember all that she told me about the paintings, their background, their meaning, and the people depicted in them. Later, after having met up with Jack, I asked him about some of the same murals without informing him of any prior knowledge. I wanted to hear the differences in the stories. Catholics do not take the time to learn the stories of the Protestant murals, and the same goes the other way around. When there is a piece significant to both, the stories are spun differently telling the different truths of the different tellers.

We came to a mural on the back side of a building on the outskirts of lower Shankill Road, a Protestant area. The mural spanned the entire back wall of a large storage building. Its Protestant blue made it quite noticeable in its grey and brown environment. The portrait painted was of Lieutenant Colonel William McCullough, a member of the Ulster Defense Association (UDA) known for jailing active paramilitary members, particularly those in the Provisional IRA. Mary had deemed the man a hero while Jack had called him a murderer. "He wasn't just jailing members of the IRA. He was torturing them. Sure, paramilitary groups were illegal, but he wasn't too concerned about the UVF or UFF roaming around here.” Surprisingly, Jack admitted that he knew the men who murdered Lieutenant Colonel McCullough. They were friends of his in the Irish National Liberation Army (INLA). Jack explained how they watched the political leader for weeks, mapping out his every move. "He dropped his girls off at school the same time every day. He picked them up the same time every day. When the time was right, these buddies of mine drove by on a motorcycle. One shot him while the other continued driving." I later discovered that the authorities still do not know who murdered William "Bucky" McCullough, and I do not think anyone who knows plans to tell any time soon. A hero to one is a murderer to another, and so it goes with many of the portraits which fill the murals of Belfast.

Jack showed me one last mural. It was one with a smashed window, and the Irish flag laying shredded on the windowsill. As the Irish flag spills out of the window, it joins a mosaic of other flags. It is surrounded with a message of equal representation:

Over 40 years ago the presence of this flag-on this street unleashed a vicious campaign of discrimination and violence against this community lasting decades . . 45 years on, this flag can flow freely from every corner. All flags are welcome on this road AND SO ARE YOU.

This mural, which begins the Catholic block on Shankill Road, is part of one that tells the origin of the murals in Belfast. It tells the story of unequal representation and a biased presentation of events in Northern Ireland, and it attempts to correct the history.

What the world saw during the Troubles was controlled by the $\mathrm{BBC}$, the British broadcasting network run by Loyalists, so the Irish Catholics and Nationalists took to using their art as a way of telling the world their version of the truth. "They couldn't censor our art," Jack explained when he showed me this particular mural. "Well, they tried. We'd put something up, they'd paint over it. By the next morning, it'd be up again. After a while, they just gave up.”

Two murals, in particular, which are used to "tell the truth" of events during the Troubles are standing in West Belfast, one painted in 1971 and the other in 1976. Both murals are portraits of children, the first of a girl, Annett McGavigan, and the second a boy, Brian Stewart. Both children were shot by the British Royal Army when they had entered areas of frequent rioting. Both children were said to have been trying to obtain rubber bullets left behind from earlier riots.

"You see this?," Jack said as he pulled a dark green object out of the passenger side of his cab. "It's a rubber bullet." He carried it around so he could show it to people on his political tours. It was thick and heavy, about 4 inches in length with a diameter of nearly 2 inches. "Petitions are going around trying to outlaw the use of these on animals when hunting, and yet the British Army thought it was okay to use them on children in the streets."

When Brian Stewart's death made national news, the story was broadcasted by the state, comprised entirely of loyalists in 1976, as a defensive move. BBC led the story of Brian's death with Brian being guilty of trying to start a riot (Carlin 2006). The British Army representative was given airtime just days after Brian had been shot in the face with a plastic bullet. In the interview the representative, speaking of what had happened to Brian, said, "He got what he deserved" (Carlin 2006). So, the story that went out to the world in early October 1976 spoke of a thirteen-year-old boy leading an uprising. The story that was told to the state by eye-witnesses was different, one in which a boy found himself reaching for a used plastic bullet in the wrong place at the wrong time (Curtis 1982). On the lower, right-hand corner of the mural, there is a message from Brian's sister: "No person deserves this."

"The pictures are our way of getting the truth out, see? Brits aren't going to make themselves look bad, they'll sell what they need to to cover their asses. We tell the real stories right here," Jack pointed to the wall 
in front of us. The picture of Brian Stewart, a constant thirty-foot high reminder of another reason for the "real Irish" not to trust the British Loyalists. That is what the murals are for both sides. For those who are still close to the conflict, the murals serve as reminders of injustice, of death, of life, of victory and defeat, and for those who are more hopeful, of peace. The murals began as a mode of communication for the Irish Catholics, but they became a platform for everyone with a message.

\section{The Message Proclaimed}

The message which each person in Belfast seeks to declare is one that promotes her own thought system, her own beliefs and behaviors, above all her own religion. As previously discussed, religion is a core component to life in Belfast. You are either Protestant or Catholic-perhaps you are one hoping for peace with the other, but you lay claim to one nonetheless. The conflict that is present, from a secular perspective, tells a story of human history, progression, and regression. It is possible to view Belfast in these political terms alone, although doing so may not tell much about what is beneath the surface. It can be said that Belfast is a culture built from, or almost entirely on, religion. Therefore, it would be a vain effort to try and understand Post-War Belfast without first examining its religions and what they says about the people who call Belfast home.

So we might ask, "What does the behavior of Belfast's citizens say about who God is?" Or, furthermore, "What does it say about the world that He created?" The Christian narrative depicts God as three different but equal persons, Father, Son, and Holy Spirit. On some occasions in Scripture, these equal but different persons can be seen in what seems to be a difference with one another. The best example takes place in the garden of Gethsemane, where the readers of the Gospels find Jesus in a moment of inner turmoil. "[H]e (Jesus) fell on his face and prayed, saying, "My Father, if it be possible, let this cup pass from me; nevertheless, not as I will, but as you will” (Matt 26:39 ESV)." While Jesus relents to the will of the Father, what the readers of Matthew are witnessing is one part of the Trinity (the Son) being coerced/encouraged by another part (the Spirit) to carry out the desires of yet another (the Father). Now, this terminology, "coerced," is not necessarily a correct, or appropriate, description of the Godhead, but it does give some explanation to the inner conflict that humanity experiences in the world. This struggle, or difference, within the Trinity speaks of the human condition. It says that we, too, are in conflict, or struggle, within ourselves. The Apostle Paul, speaking of human nature, writes, "I know what I must do and still I do not do it, and that which I do, I hate" (Rom 7:15,19 ESV). In the example of Gethsemane, the Son desires to live, and for a fleeting moment he beseeches the Father to let the cup which holds his future pass from him. Here, again, we see the imagery of the cup that is given to the individual, and as much as we may struggle with it, the cup must still be taken. Humanity, in all of its searching and trying and do-gooding, cannot escape conflict and struggle. It is in every cup given to us.

What is going on here in this image of Jesus in the garden? We know that it is a struggle of some kind, internal conflict or difference perhaps. Christians do not believe that God is not in unity with Himself. What is being witnessed is the human part of Jesus struggling with the will of the Father. Jesus, fully God yet fully human, is wrestling with human nature, with human desires, and yes, with God. And if Jesus, wholly human, found himself in conflict and tension at times, is it not permissible to assume that conflict and tension is somehow human? If in this story, we read Jesus, a perfect human being, as someone who struggles within himself and outside of himself, then is it feasible to extend a standard of "no conflict" to every imperfect person in Belfast or on this earth? Or should we offer some grace, and hope that grace is extended in turn? Because no person, for we are all human, is free from pre-conceived notions, polluted perceptions, and ethnocentric desires, we are all led into conflict with others and with ourselves.

To be free from such things would be a beautiful relief, a path to genuine change and authentic goodness. Such freedom could change not only the cognitive patterns and behaviors of an individual but of the world. However, the possibility of this freedom does not come easily. The fact of the matter is, every human is born into a whole host of things over which they have no control. Surely every individual is capable of making his or her own choices, but ultimately no one individual has control over the course of history or culture. A rare revolutionary individual may come along from time to time and change things, but can a person fault every individual in all of Belfast for not being this person? No. There is no one who can "cast the first stone" and hold these individuals and the whole culture morally culpable for the harms they have done to each other. Most people do not have it within themselves to escape their cultural boundaries.

\section{Belfast's Inverted Social Structure}

The revolutionary social theorist, Karl Marx, investigated notions of conflict and their relation to social structures. According to Marx, all people in modern societies live in circumstances of conflict (Marx 2000, 30). Marx's conflict theory helps makes sense of the situation in Belfast. As Marx separated society into 
the bourgeoisie and the proletariat, so Belfast, too, is separated into the haves and the have nots. In this case, they are labeled "those too far removed from the conflict" and "those too close to the conflict," respectively. While Marx decried the injustice against the latter, he thought conflict was not only normal but "good", since it is necessary to bring about change in society (Marx 2013, 9).

Belfast illustrates Marx's point that a society in which one group exploits another will "contain the seeds of its own destruction” (Marx and Engels 1850). In Belfast, this destruction can be seen in that the peace which the government hopes to obtain for Northern Ireland is prevented by its own hand. In a city in which the Council has no intention of creating unity from the top down, its people have no intention of creating unity from one side to the other. This destruction, as multiple studies have suggested, is seen in the multiple oppressions that are found in the city. The Protestants have oppressed the Catholics throughout history and now, the Catholics have retaliated and oppress the Protestants, the government oppresses the workingclass, the wealthy Protestants oppress the poor Protestants, the poor Catholics are oppressed by the wealthy Catholics, the police oppress the citizens, the citizens oppress the police, and the seeds of destruction continue to scatter. There are no neat lines which can be drawn in Belfast, and at times it seems as though every man and woman is not only for themselves, but intentionally against each other.

It is true that Marx's theory focused on class conflict and predicted the triumph of the working class over the middle classes. In this, Belfast does not necessarily fit the model, since the two combatting classes have yet, despite centuries of conflict, to reach that moment of triumph in which "those too close to the conflict" will triumph over "those two far removed." It seems that "those too close to the conflict" would rather feud amongst themselves along religious lines.

Belfast may not fit the specifics of Marx's theory, but it is through the lens of his theory that one can understand why it is that there has not yet been peace or agreement in Northern Ireland. For change to occur, so says Marx, capitalism, which is a product of feudalism, must resolve itself into socialism (Marx 2013, 13). Socialism is the idea of a community working together as a single unit to produce a society in which all of its members are thriving. In Marx's theory it is powerlessness and inequality, such as that the civilians of Belfast feel, that unite the working class and create societal change. However, Belfast is so deeply separated by religion that most cannot envision the kind of "class consciousness" that Marx thought would bring about the revolution to a peaceful community.

In Marx's theory, religion is secondary to class, meaning he thought that one's religious or political stance stemmed from one's material conditions or economic role in society. In Belfast, it can be argued that the opposite is true. Ultimately religion, followed closely by politics, is what decides the distribution of resources and labor opportunities that are available to a person. What Marx viewed as the superstructure of a society is actually the foundation for Belfast's conflict. The inversion of the foundation with the superstructure explains why no resolution has yet been achieved in Belfast.

\section{Conclusion}

To wrap this up into a concise, although not neat, package, the culture of conflict in Post-War Belfast is, today, a problem of cognition. The crisis continues to prevail because minds continue to think that they are still at war. Those who are "too close to the conflict" accept their role in the battle, and even "those who are too far removed", with their hopes of peace and reconciliation, yet find themselves in the midst of cultural combat. The battle rages now, as it did in history, because each person lives according to the cup they have been given, according to the frameworks which were laid for them, and according to the place in which they find themselves. The people who are "too close to the conflict" are not to be blamed for the violence that was bred into them, for to them, their actions are not violent, they are loyal, they are justified, and they are right. Those who are "too far removed" are not to be blamed for their ineffectual idealism, for to them their actions are not careless or selfish, they are profitable, they are sustainable, and they are right.

Humans are born into a world of truth and falsity, but not of absolutes. This is the general acceptance of anthropologists. There is most certainly truth, but truth differs from culture to culture. There is most certainly that which is ethical, moral, and right, but these things also differ from culture to culture. The two inhabiting groups of Belfast, "those too close" and "those too far removed," and the cornucopia of branching subgroups, live together within the 44 square miles of Belfast, but they may as well be on opposite sides of the world. From one street to the next, what is truth and what is right, cannot be spoken of with certainty by an outsider. We can look at the hurt in Belfast, at the countless lives lost, and our hearts can break for them. We can possess anger, or empathy, or resentment, but we cannot judge, because we do not know their truths. We do not live their lives; we do not experience their existence. We can idealistically hope for reconciliation, but for now the city of Belfast will continue to live separated. 


\section{Bibliography}

Benedict, Ruth. 1934. Patterns of Culture. New York: Houghton Mifflin.

Berger, Peter L., and Thomas Luckmann. 1991. The Social Construction of Reality: A Treatise in the Sociology of Knowledge. London: Penguin Books.

Boas, Franz. 1910. Psychological Problems in Anthropology. American Journal of Psychology 21:371384.

Carlin, Davy. 2006. The Murder of Brian Stewart. Indymedia. https://www.indymedia.ie/article/73973? userlanguage=ga \&save_prefs=true Accessed October 13, 2018.

Central Statistics Office. 2016. Census 2016- Part 1. https://www.cso.ie/en/media/csoie/newsevents/document s/census2016summaryresultspart1/Census2016Summary

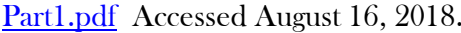

Curtis, Liz. 1982. They Shoot Children: The Use of Rubber and Plastic Bullets in the North of Ireland. London: Information of Ireland.

Feeney, Brian. 2004. A Short History of the Troubles. Dublin: O’Brien Press.

Kapur, Raman, and Jim Campbell. 2004. The Troubled Mind of Northern Ireland: An Analysis of the Emotional Effects of the Troubles. London: Routledge.

McAlister, S., D. Haydon, and P. Scraton. 2013. Violence in the Lives of Children and Youth in 'Post-Conflict' Northern Ireland. Youth and Environments 23:1-22.

Maguire, William. 2009. Belfast: A History. Lancaster: Carnegie Publishing Ltd.

Marx, Karl, and Frederick Engels. "Address of the Central Committee to the Communist League." 1850. Transcribed by Alex Blain 2006. https://www.marxists.org/archive/marx/works/1847/com munist-league/1850-ad1.htm Accessed November 2018.

Marx, Karl, and Frederick Engels. 2013. Manifesto of the Communist Party. New York: Start Publishing LLC.

Marx, Karl. 2000. Capital: A Critique of Political Economy vol. I. London: Electric Book Company.

Meulemans, Bill. 2013. Belfast: Both Sides Now. Charleston: CreateSpace Publishing.

New World Encyclopedia. 2008. Norman Invasion of Ireland. http://www.newworldencyclopedia.org/entry/Norman_in vasion_of_Ireland Accessed May 23, 2018.
Smith, Nicole. 2018. A Culture of Conflict: An Examination of Cognitive Processes and Behaviors of Citizens in Post-War Belfast. Master's thesis. Eastern University.

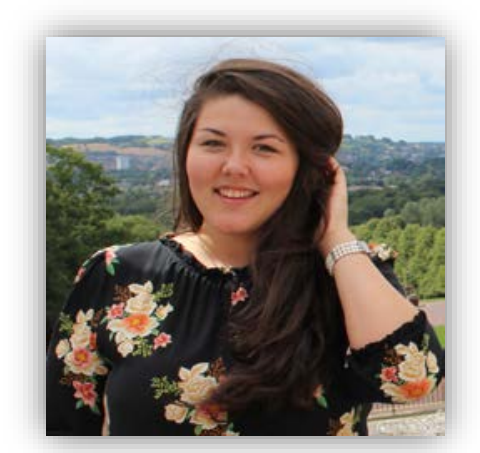

Nicole Finnell Smith graduated with her Bachelor of Science in Pre-Medicine and Biblical Studies from Evangel University. It was here that she began her interest in culture and humanity. She took her first trip abroad to India (2014) and later followed this with a time in Sri Lanka (2015), Mexico (2016), and Northern Ireland (2018). She can most likely be found perusing bookstores, sipping in coffee shops, or advocating for self-care and body positivity. She spends her free time with her husband Caleb and cat Aurora in South Carolina.

Author email: finnellnicole@gmail.com 